\section{KAJIAN TERHADAP TINDAKAN INSIDER TRADING SEBAGAI BENTUK PELANGGARAN TRANSAKSI BISNIS DI PASAR MODAL PADA ERA GLOBAL $^{1}$}

Oleh: Jelita G. Rondonuwu²

Ronald J. Mawuntu ${ }^{3}$

Anna Wahongan ${ }^{4}$

\begin{abstract}
ABSTRAK
Tujuan dilakukannya penelitian ini adalah untuk mengetahui bagaimana aturan hukum terhadap tindakan insider trading yang dilakukan pada Pasar Modal di Indonesia di era global dan bagaimana bentuk-bentuk sanksi terhadap tindakan insider trading yang dilakukan pada Pasar Modal di Indonesia. Dengan menggunakan metode peneltian yuridis normatif, disimpulkan: 1. Aturan hukum terhadap tindakan Insider Trading yang dilakukan pada Pasar Modal di Indonesia, di era global saat ini, terdapat pada Pasal 95 UUPM yang secara tegas melarang orang dalam melakukan transaksi efek dengan menggunakan informasi orang dalam (insider trading). 2. Bentuk-bentuk sanksi terhadap tindakan insider trading yang dilakukan pada Pasar Modal di Indonesia, diatur pada UUPM yaitu berupa hukuman Pidana penjara selamalamanya 10 tahun dan denda setinggitingginya 15 milyar Rupiah (Pasal 104). Sanksi hukum bagi orang dalam (Insider) di Pasar Modal Indonesia khususnya merupakan sanksi hukum administratif. Untuk pelanggaran yang dilakukan sanksinya adalah ganti rugi atas kerugian yang diderita investor yang melakukan perdagangan saham perusahaan dengan dasar kepercayaan atas pernyataan atau informasi yang di-disclose oleh perusahaan.
\end{abstract}

Kata kunci: Kajian, Tindakan Insider Trading, Bentuk Pelanggaran, Transaksi Bisnis, Pasar Modal, Era Global

\section{PENDAHULUAN}

\section{A. Latar Belakang Penelitian}

Pasar modal Indonesia sebagai salah satu lembaga yang memobilisasi dana masyarakat

\footnotetext{
${ }^{1}$ Artikel Skripsi

2 Mahasiswa pada Fakultas Hukum Unsrat, NIM : 15071101014

${ }^{3}$ Fakultas Hukum Unsrat, Guru Besar IImu Hukum

${ }^{4}$ Fakultas Hukum Unsrat, Doktor IImu Hukum
}

dengan menyediakan sarana atau tempat untuk mempertemukan penjual dan pembeli dana jangka panjang yang disebut efek, dewasa ini telah merupakan salah satu pasar modal negara berkembang secara fantastis atau dinamik. Disebut fantastik, karejumlah uang beredar yang sangat besar yang dilakukan oleh para investor yang bertransaksi, dinamik karena perputarannya yang sangat cepat dari waktu ke waktu.

Pasar modal adalah kegiatan yang bersangkutan dengan penawaran umum dan perdagangan efek, perusahaan publik yang berkaitan dengan efek yang diterbitkannya serta lembaga dan potensi yang berkaitan dengan efek. ${ }^{5}$ Melalui transaksi dipasar modal seorang investor berharap untuk mendapatkan keuntungan dari transaksi-transaksi yang dilakukan. Ada yang dilakukan secara benar dan legal, namun ada juga cara-cara curang yang dilakukan untuk mengelabui publik atau memanfaatkan kesempatan dari informasi yang diterima terlebih dahulu.

Undang-Undang Nomor 8 Tahun 1995 yaitu Undang-Undang Pasar Modal merupakan salah satu bukti bahwa Pasar Modal memang harus mendapat perhatian yang sangat serius, terutama untuk mengatur kegiatan operasi lembaga ini dan memberi perlindungan terhadap semua pihak yang bertransaksi. Dalam perkembangannya, meski telah diatur melalui undang-undang, akan tetapi permasalahan yang berkaitan dengan Pasar Modal menjadi salah satu halyang menjadi perhatian yang serius dari publik, terutama dalam rangka menciptakan keamanan, kenyamanan dan kepercayaan investor terhadap transaksi Pasar Modal.

Satu hal yang berhubungan dengan kepercayaan investor untuk bertransaksi, yaitu tidak diperbolehkannya tindakan-tindakan oleh perusahaan atau individu tertentu, yang tidak sesuai dengan prinsip-prinsip keterbukaan. Tindakan-tindakan ini, pada akhirnya merupakan tindakan yang akan merugikan kepentingan publik serta merugikan dan menghambat keberlangsungan proses pembangunan ekonomi nasional.

Pelanggaran-pelanggaran yang dapat terjadi pada proses transaksi di pasar modal, ada yang

\footnotetext{
5 Undang-undang Pasar Modal Republik Indonesia Nomor 8 Tahun 1995 Pasal 1 butir 13.
} 
dapat berupa pelanggaran administratif, atau pelanggaran-pelanggaran yang dapat dikategorikan sebagai suatu kejahatan atau tindak pidana di pasar modal. Salah satu bentuk tindak pidana di pasar modal seperti yang diatur dalam Undang-Undang No 8 Tahun 1995 tentang Pasar Modal, yaitu apa yang dikenal dengan nama Insider Trading.

Insider Trading atau yang lebih dikenal dengan perdagangan dengan informasi orang dalam, akan sangat merugikan baik bagi para investor yang akan melakukan investasi karena pihak yang lain sudah mengambil keuntungan lebih dahulu sebelum informasi itu diumumkan secara resmi kepada publik, maupun terhadap perekonomian nasional, karena hilangnya kepercayaan para investor terhadap transaksi yang akan dilakukan di Indonesia. Hal ini tentu menarik untuk dikaji secara ilmiah dalam bentuk skripsi.

\section{B. Perumusan masalah}

1. Bagaimanakah aturan hukum terhadap tindakan insider trading yang dilakukan pada Pasar Modal di Indonesia di era global ?

2. Bagaimanakah bentuk-bentuk sanksi terhadap tindakan insider trading yang dilakukan pada Pasar Modal di Indonesia ?

\section{Metode Penelitian}

Penelitian ini menggunakan metode penelitian yang termasuk jenis penelitian normatif, di mana didalamnya penulis meneliti dan mempelajari norma yang terdapat dalam peraturan perundang-undangan ataupun norma yang mengatur tentang tindakan insider trading sebagai bentuk pelanggaran transaksi bisnis di pasar modal pada era global sehingga dalam pelaksanaannya sesuai dengan peraturan perundang-undangan yang berlaku.

Melengkapi dan mendukung serta memperjelas analisis terhadap peraturan perundang-undangan diteliti seperti : Bahan hukum primer, yaitu bahan yang sifatnya mengikat masalah-masalah yang akan diteliti seperti Undang-undang No. 8 Tahun 1995 tentang Pasar Modal. Bahan hukum sekunder, yaitu bahan yang memberikan penjelasan mengenai bahan hukum primer. Penulis akan meneliti buku-buku ilmiah hasil karya di kalangan hukum yang ada relevansinya dengan masalah yang diteliti, memahami bahan hukum primer adalah rancangan peraturan perundangundangan, hasi-hasil penelitian, hasil-hasil karya ilmiah para sarjana.

\section{PEMBAHASAN}

A. Aturan Hukum Terhadap Tindakan Insider Trading Yang Dilakukan Pada Pasar Modal di Indonesia di Era Global

Insider trading merupakan istilah teknis yang hanya dikenal di pasar modal. Istilah tersebut mengacu kepada praktik di mana orang dalam (corporate insider) melakukan transaksi sekuritas dengan menggunakan informasi eksklusif yang mereka miliki belum tersedia bagi masyarakat atau investor. ${ }^{6}$

UUPM memberikan batasan terhadap transaksi yang dilarang antara lain orang dalam dari emiten yang mempunyai informasi orang dalam, dilarng melakukan transaksi penjualan atau pembelian atas efek emiten atau perusahaan lain yang melakukan transaksi dengan atau perusahaan publik yang bersangkutan. Berdasarkan batasan tersebut di atas, maka dapat ditentukan bahwa perdagangan efek dapat digolongkan sebagai praktik insider trading, apabila memenuhi tiga unsur minimal, yaitu : ${ }^{7}$

a. Adanya orang dalam

b. Informasi materiel yang belum tersedia bagi masyarakat atau belum diclosure;

c. Melakukan transaksi karena informasi material.

UUPM mengatur mengenai pelarangan baik secara langsung maupun tidak langsung dalam melakukan penawaran, pembelian, dan/atau penjualan efek yang terjadi dalam rangka penawaran umum, atau di bursa efek atau di luar bursa efek emiten atau perusahaan publik, melakukan tindakan sebagai berikut :

a. Secara langsung atau tidak langsung menipu atau mengelabui pihak lain dengan menggunakan sarana atau cara apapun; turut serta menipu atau mengelabui pihak lain; dan membuat pernyataan tidak benar mengenai fakta material atau tidak

\footnotetext{
${ }^{6}$ Najib, Tinjauan Umum Terhadap Pasar Modal Indonesia, Makalah diskusi pada mata kuliah hukum perusahaan, Program Magister Ilmu Hukum UII, 18 Januari 1997, hlm. 19.

${ }^{7}$ Najib A. Gisymar, Op.Cit, hlm. 34.
} 
mengungkapkan mengenai keadaan yang terjadi pada saat pernyataan dibuat, dengan maksud untuk menguntungkan atau menghindarkan kerugian untuk diri sendiri atau pihak lain atau dengan tujuan memengaruhi pihak lain untuk membeli atau menjual efek (Pasal 90 UUPM)

b. Melakukan tindakan, baik langsung maupun tidak langsung dengan tujuan untuk menciptakan gambaran semu atau menyesatkan mengenai kegiatan perdagangan, keadaan pasar atau harga efek di bursa efek (Pasal 91 UUPM)

c. Baik sendiri-sendiri maupun bersama dengan pihak lain, dilarang melakukan 2 (dua) transaksi efek atau lebih baik langsung maupun tidak langsung, sehingga menyebabkan harga efek di bursa efek tetap, naik atau turun dengan tujuan memengaruhi pihak lain untuk membeli, menjual atau menahan efek (Pasal 92 UUPM).

d. Dengan cara apapun membuat pernyataan atau memberikan keterangan yang secara material tidak benar atau menyesatkan, sehingga memengaruhi harga efek di bursa efek, apabila pada saat pernyataan dibuat atau keterangan diberikan :

1. Pihak yang bersangkutan mengetahui atau sepatutnya mengetahui bahwa pernyataan atau keterangan tersebut secara material tidak benar atau menyesatkan; atau

2. Pihak yang bersangkutan tidak cukup berhati-hati dalam menentukan kebenaran material dari pernyataan atau keterangan tersebut (Pasal 93 UUPM)

UUPM secara tegas melarang orang dalam melakukan transaksi efek dengan menggunakan informasi orang dalam (insider trading). Dlam penjelasan Pasal 95 UUPM disebutkan bahwa yang dimaksud dengan "orang dalam", adalah :

a. Komisaris, direktur atau pegawai emiten atau perusahaan publik;

b. Pemegang saham atau emiten atau perusahaan publik

c. Orang perorangan yang karena kedudukannya atau profesinya atau karena hubungan usahanya dengan emiten atau perusahaan publik memungkinkan orang tersebut memperoleh informasi orang dalam

d. Pihak yang dalam waktu 6 (enam) bulan terakhir tidak lagi menjadi pihak sebagaimana dimaksuddalam huruf a,d, atau $\mathrm{c}$ di atas.

Memperhatikan ketentuan Pasal 95 UUPM di atas, kita mengetahui bahwa insider trading merupakan praktek yang sangat dilarang dalam perdagangan efek di pasar modal di negara manapun juga. Oleh karena itu, sebagaimana ditegaskan dalam Pasal 95 UUPM, orang dalam dari emiten atau perusahaan publik yang mempunyai informasi orang dalam dilarang melakukan pembelian atau penjualan atas efek $:^{8}$

1. Emiten atau perusahaan publik dimaksud, atau

2. Perusahaan lain yang melakukan transaksi dengan emiten atau perusahaan publik bersangkutan

Pasal 96 UUPM mengatur, bahwa orang dalam sebagaimana dimaksud dalam Pasal 95 UUPM tersebut dilarang memengaruhi pihak lain untuk melakukan pembelian atau penjualan atas efek dimaksud, atau memberikan informasi orang dalam kepada pihak mana pun yang patut diduganya dapat menggunakan informasi dimaksud untuk melakukan pembelian atau penjualan atas efek.

Dengan demikian, pasal tersebut mempunyai pengertian bahwa setiap pihak yang berusaha untuk memperoleh informasi orang dalam dari orang dalam secara melawan hukum dan kemudian memperolehnya, akan dikenakan larangan yang sama dengan larangan yang berlaku bagi orang sebagaimana dimaksud dalam Pasal 95 dan 96 UUPM.

\section{B. Bentuk-Bentuk Sanksi Terhadap Tindakan Insider Trading Yang Dilakukan Pada Pasar Modal Di Indonesia}

Melihat perkembangan kejahatan insider trading yang dilakukan akhir-akhir ini. Maka peraturan atau hukumpun harus berusaha mengikuti perkembangan tersebut. Dengan demikian, diperlukan suatu doktrin atau teori baru yang dapat menjerat para pelaku kejahatan tersebut, yang tidak dapat terjerat oleh peraturan sebelumnya. Mengingat kejahatan bisnis ini motif operandinya sudah

8 Jusuf Anwar, Op.Cit, hlm. 108. 
sedemikian beragam, seperti apa yang dilakukan oleh Enron Corp dan WorldCom Inc., kedua perusahaan tersebut telah melakukan pembohongan publik (misrepresentation) dengan merekayasa laporan keuangan mereka (accounting fraud). ${ }^{9}$

Bank Lippo di Indonesia, pernah diduga melakukan kejahatan serupa, yaitu accounting manipulation. Pada saat itu, Bapepam telah menjatuhkan denda administratif kepada Direksi Bank Lippo sebesar 2,5 miliar rupiah atas pelanggaran membuat 2 macam laporan (audit dan un audit) karena kelalaian.

Kelemahan UUPM pada saat itulah, diakui Bapepam kurang memperoleh kewenangan menembus rekening pelaku pasar modal yang diduga melakukan pelanggaran. ${ }^{10}$ Oleh karena itu, Bapepam meminta agar UUPM diamandemen agar memiliki "power" untuk mengakses data rekening sekuritas, bank maupun data-data lembaga keuangan lainnya. Melalui cara ini, diharapkan pelanggaran pasar modal dapat diminimalisasi. Karena saat ini, sangat sulit menelusuri jejak para pelaku pelanggaran pasar modal, Bapepam tidak memiliki kewenangan untuk mengakses langsung data-data rekeningh orang-orang yang diduga melakukan pelanggaran.

Adanya UU No. 21 Tahun 2011 tentang Otoritas Jasa keuangan, kewenangan OJK sudah cukup luas. Pelaksanaan fungsi bidang Pengawasan Sektor Pasar Modal mempunyai tugas pokok :

1. Menyusun peraturan pelaksanaan di bidang Pasar Modal.

2. Melaksanakan Protokol Manajemen Krisis Pasar Modal

3. Menetapkan ketentuan akutansi di bidang Pasar Modal

4. Merumuskan standar, norma, pedoman kriteria dan prosedur di bidang Pasar modal

5. Melaksanakan analisis, pengembangan dan pengawasan Pasar Modal termasuk Pasar Modal Syariah

6. Melaksanakan penegakan hukum di bidang Pasar Modal

\footnotetext{
9 M.S. Tumangor, Kajian Hukum Atas Insider Trading di Pasar Modal Suatu Antisipasi Terhadap Pengembangan Ekonomi Indonesia, Dalam Warta Bapepam, Edisi 8 Agustus 2005, Jakarta, hal. 145.

10 Ferdy Hasiman, Bapepam Minta UU Pasar Modal Segera Diamankan, http://www.inilah.com, diakses pada bulan Desember 2009.
}

7. Menyelesaikan keberatan yang diajukan oleh pihak yang dikenakan sanksi oleh OJK, Bursa Efek, Lembaga Kliring dan Penjaminan, dan Lembaga Penyimpanan dan Penyelesaian;

8. Merumuskan prinsip-prinsip Pengelolaan Investasi, Transaksi dan Lembaga Efek, dan tata kelola Emiten dan Perusahaan Publik;

9. Melakukan pembinaan dan pengawasan terhadap pihak yang memperoleh izin usaha, persetujuan, pendaftaran dari OJK dan pihak lain yang bergerak di bidang pasar modal.

10. Memberikan perintah tertulis, menunjuk dan/atau menetapkan penggunaan pengelola statuter terhadap pihak/lembaga jasa keuangan yang melakukan kegiatan di bidang Pasar Modal dalam rangka mencegah dan mengurangi kerugian konsumen, masyarakat dan sektor jasa keuangan, dan

11. Melaksanakan tugas lain yang diberikan oleh Dewan Komisioner (www.ojk.go.id).

Salah satu modus kejahatan bisnis di pasar modal adalah insider trading. Ini terkait dengan hukum pasar modal yang diatur dalam UU No. 8 Tahun 1995 tentang Pasar Modal. Insider trading adalah perdagangan saham atau surat berharga lain milik perusahaan oleh individu dengan akses potensi untuk mendapatkan informasi non-publik tentang perusahaan. Istilah ini sering digunakan untuk merujuk kepada praktik di mana orang adalam atau perdagangan pihak terkait berdasarkan bahan informasi yang non-publik yang diperoleh selama pelaksanaan tugas orang dalam tersebut di perusahaan yang dimaksud. Dengan kata lain, orang tersebut menyalahgunakan informasi non-publik dari perusahaan yang kemudian digunakan untuk kepentingan golongan tertentu. Pemberian infomasi yang non-publik ini sangat penting untuk membuat keputusan baik untuk membeli atau menjual saham atau surat berharga lainnya.

Kejahatan pasar modal yang paling terkenal dan sangat merugikan masyarakat dewasa ini adalah berupa penipuan, penyebarluasan Informasi yang tidak benar atau menyesatkan (misleading information) dan manipulasi pasar yang diakibatkan oleh "orang dalam" yang memanfaatkan informasi orang dalam atau 
yang populer dengan insider trading atau perdagangan orang dalam.

Informasi tersebut umumnya belum atau tidak disiarkan kepad masyarakat, sehingga akibat investor akan salah dalam memutuskan untuk membeli atau menjual sahamnya yang disebabkan oleh data yang diberikan para emiten tidak kuat. Dengan demikian, insider trading menjadi salah satu kejahatan bisnis yang dilakukan di dalam pasar bebas, sebagai bentuk kejahatan abad globalisasi. Tahun 2009. Di mana kasus ini bermula dari penjualan 81,95\% saham PT Petrosea kepada PT. Indika Energy senilai US\$ 83,8 juta pada 26 Februari 2009. Dalam proses penjualannya, diduga ada pihak orang dalam yang membocorkan informasi ke pihak-pihak tertentu, sehingga ada pihak-pihak yang tahu lebih dahulu ketimbang publik. ${ }^{11} \mathrm{Hal}$ ini yang membuat, pihak-pihak tertentu tersebut diuntungkan oleh naiknya harga saham.

Oleh karena itu, kewajiban emiten dalam memberikan informasi yang akurat dan transparan kepada publik adalah sesuatu hal yang sangat penting sekali dalam perdagangan saham di pasar modal. Selanjutnya, hal yang penting untuk diperhatikan dalam pengembangan pasar modal adalah prinsipprinsip keterbukaan dan perlindungan para investor. ${ }^{12}$ Ini berarti, para investor tidak hanya mendapatkan informasi yang akurat, tetapi juga memberikan jaminan hukum yang baik juga sangat diperlukan.

Pengertian "kejahatan bisnis", secara filosofis mengandung makna terjadinya perubahan nilai-nilai (value) dalam masyarakat ketika suatu aktivitas bisnis dioperasikan sedemikian rupa sehingga sangat merugikan kepentingan masyarakat luas, ${ }^{13}$ seperti kegiatan pasar modal ini, di mana para pemegang sahamnya adalah masyarakat luas. Perubahan nilai yang terjadi, adalah kurangnya para pengusaha menghargai kejujuran dalam kegiatan bisnisnya.

Fenomena terjadinya kejahatan pasar modal berupa penipuan, menyebarluaskan informasi yang tidak benar atau menyesatkan (misleading

\footnotetext{
11 Samsul Maarif, BEl: Transaksi INDY "Insider Trading, http://www.inilah.com, diakses pada bulan Desember 2009.

12 Jusuf Anwar, Op.Cit, hlm. 4.

${ }^{13}$ Romli Atmasasmita, Op.Cit, hlm. 114.
}

information) yang dilakukan oleh orang dalam (insider trading), menjadi sangat menarik untuk dibahas, mengingat kejahatan ini menjadi bentuk kejahatan gaya baru dalam era globalisasi saat ini. Demikian juga halnya dengan pembuktiannya, kejahatan bentuk ini juga sangat sulit untuk dilacak. Model kejahatan ini, menyebabkan begitu banyak investor yang merugi, akibat kesalahan informasi dalam menentukan investasi.

Dilarangnya perdagangan oleh orang dalam ini sangat berkaitan dengan adanya ketentuan yang mengatur tentang 'keterbukaan informasi' yang harus diumumkan kepada publik, sebagaimana diatur dalam Keputusan Ketua Bapepam No.Kep-22/PM/1991. Keputusan Ketua Bapepam ini mewajibkan setiap perusahaan publik untuk menyampaikan kepada Bapepam dan mengumumkan kepada masyarakat secepat mungkin, paling lambat akhir hari kerja kedua setelah Keputusan atau terjadinya suatu peristiwa, keterangan penting dan relevan yang mungkin dapat mempergunakan nilai efek perusahaan atau keputusan investasi nilai efek perusahaan atau keputusan investasi pemodal.

Perlu juga ditekankan di sini bahwa perdagangan oleh orang dalam ini tidak saja mengakibatkan terjadinya suatu tindak pidana tetapi juga merupakan suatu perbuatan melawan hukum menurut ketentuan Pasal 1365 KUH Perdata. Hal ini karena perdagangan oleh orang dalam itu dapat merugikan investor lain dan karenanya investor yang dirugikan berhak mendapatkan penggantian apabila dapat membuktikannya. Oleh karena itu menurut ketentuan Pasal 1365 KUH Perdata maka "tiap perbuatan melanggar hukum, yang membawa kerugian kepada orang lain, mewajibkan orang yang karena salahnya menerbitkan kerugian itu, mengganti kerugian tersebut".

Terkait dengan diaturnya Insider Trading atau perdagangan orang dalam sebagai suatu tindak pidana, maka hal tersebut tidak dapat dilepaskan dari adanya proses penyidikan atas tindak pidana yang terjadi. Dalam UndangUndang No. 8 Tahun 1995, proses penyidikan terhadap tindak pidana yang di bidang pasar modal, termasuk tindak pidana Insider Trading atau perdagangan oleh orang dalam, diatur dalam bab XIII. 
Undang-Undang Nomor 8 Tahun 1995 Tentang Pasar Modal. Sanksi atas pelanggaran yang dilakukan orang dalam (Insider) terdapat dalam Pasal 95 adalah hukuman pidana penjara selama-lamanya 10 tahun dan denda setinggitingginya 15 milyar rupiah (Pasal 104). ${ }^{14}$ Sanksi hukum bagi orang dalam (Insider) di Pasar Modal Indonesia khususnya merupakan sanksi hukum administratif untuk pelanggaran Rule 10b-5sanksinya adalah ganti rugi atas kerugian yang diderita investor yang melakukan perdagangan saham perusahaan dengan dasar kepercayaan atas pernyataan atau informasi yang didiscloseoleh perusahaan. ${ }^{15}$

Berdasarkan Pasal 101 ayat (2), maka proses penyidikan terhadap pelanggaran termasuk terhadap tindak pidana pasar modal dilakukan oleh Penyidik Pegawai Negeri Sipil di Lingkungan Badan Pengawasan Penanaman Modal (BAPEPAM). Dimana disebutkan bahwa Pejabat Pegawai Negeri Sipil tertentu di lingkungan Bapepam diberi wewenang khusus sebagai penyidik untuk melakukan penyidikan tindak pidana di bidang Pasar Modal berdasarkan ketentuan dalam Kitab Undangundang Hukum Acara Pidana.

Didalam rangka pelaksanaan kewenangan penyidikan sebagaimana tersebut, Bapepam dapat meminta bantuan aparat penegak hukum lain. (pasal 101 ayat 6). Dalam pelaksanaannya, ternyata proses penyidikan terhadap tindak pidana Insider Trading atau perdagangan oleh orang dalam ini sangat sulit dilaksanakan, terlebih dalam proses pembuktiannya. Badan Pengawas Pasar Modal (Bapepam) belum pernah bisa membuktikan adanya 'insider trading' atas sebuah kasus yang dilaporkan pihak-pihak lain berkaitan dengan dugaan insider trading (perdagangan orang dalam). Kepala Biro Pemeriksaan dan Penyidikan Bapepam, Abraham Bastari, menjelaskan kasus terakhir yang oleh sementara kalangan disebutkan sebagai kasus insider trading dalam perdagangan saham PT Indosat ternyata pada akhirnya tidak terbukti sebagaimana disinyalir oleh banyak pihak.

Perkembangan ilmu dan teknologi juga tak dapat dipisahkan dari berkembangnya Insider Trading. Pengaruh ilmu dan teknologi sangat

\footnotetext{
${ }^{14}$ MS. Tumangor, Op.Cit, hal. 90.

15 Asril Sitompul (1995), Pasar Modal Penawaran Umum dan Permasalahannya, Citra Aditya Bakti, Bandung.
}

besar dirasakan dalam dunia pasar modal. IImu dan teknologi dapt mempermudah terjadinya Insider Trading dan memperbesar kemungkinan mengubah cara dan prespektif orang dalam melakukan suatu tindakan tertentu. Misalnya dengan pemanfaatan internet, teknologi komunikasi (handphone dan segala fasilitasnya) akan sanagt memberi peluang bagi mengalirnya informasi dari orang dalam yang digunakan untuk melakukan suatu transaksi pasar modal yang melanggar ketentuan. Di sisi lain, kecanggihan ilmu dan teknologi tersebut menjadi kendala terbesar bagi keberhasilan pembuktian adanya Insider Trading dalam proses penyidikan tindak pidana pasar modal.

Namun demikian, hendaklah hal ini tidak dipandang sebagai suatu hambatan atau kendala yang tak terpecahkan,. Sebaiknya justru dipandang sebagai suatu tantangan yang harus dapat diatasi secara bersama dan komprehensif, antara pihak - pihak yang terkait, baik para pelaku pasar modal, pihak pengawas (BAPEPAM dan BAPPEBTI) serta pihak Kepolisian. Perlu adanya langkah nyata dan segera, misalnya adanya kepastian dan batasan atau landasan yang jelas dan pasti tentang karakteristik pemanfaatan ilmu dan teknologi dalam penyelenggaraan transaksi pasar modal, dan kerangka penyidikan tindak pidana pasar modal yang tegas, jelas dan efektif guna mengatasi semakin marak dan berkembangnya Insider Trading sebagai salah satu tindak pidana di bidang pasar modal.

\section{PENUTUP}

\section{A. Kesimpulan}

1. Aturan hukum terhadap tindakan Insider Trading yang dilakukan pada Pasar Modal di Indonesia, di era global saat ini, terdapat pada Pasal 95 UUPM yang secara tegas melarang orang dalam melakukan transaksi efek dengan menggunakan informasi orang dalam (insider trading).

2. Bentuk-bentuk sanksi terhadap tindakan insider trading yang dilakukan pada Pasar Modal di Indonesia, diatur pada UUPM yaitu berupa hukuman Pidana penjara selama-lamanya 10 tahun dan denda setinggi-tingginya 15 milyar Rupiah (Pasal 104). Sanksi hukum bagi orang dalam (Insider) di Pasar Modal Indonesia 
khususnya merupakan sanksi hukum administratif. Untuk pelanggaran yang dilakukan sanksinya adalah ganti rugi atas kerugian yang diderita investor yang melakukan perdagangan saham perusahaan dengan dasar kepercayaan atas pernyataan atau informasi yang didisclose oleh perusahaan.

\section{B. Saran}

1. Untuk menghindari terjadinya insider trading dan sanksi pidana maupun administratif yang dapat dijatuhkan, maka sebaiknya orang-orang dalam diantaranya: Komisaris, direktur atau pegawai emiten atau perusahaan publik, Pemegang saham atau emiten atau perusahaan publik, Orang perorangan atau pihak yang memperoleh informasi dari orang dalam tidak memberikan informasi apapun yang akan memungkinkan terjadinya insider trading terhadap transaksi efek yang akan dilakukan perusahaan.

2. Untuk menjaga citra perdagangan efek di Pasar Modal di Indonesia, maka sebaiknya upaya pencegahan terhadap terjadinya insider trading dilakukan secara kontinue dan melibatkan berbagai pihak terkait sebagai informan, terutama untuk mencegah orang dalam dari emiten atau perusahaan publik yang mempunyai informasi orang dalam melakukan pembelian atau penjualan atas efek.

\section{KEPUSTAKAAN}

Agus Budiarto, Kedudukan Hukumdan Tanggung Jawab Pendiri Perseroan Terbatas, Ghalia Indonesia, Bogor, 2009.

Asril Sitompul, Pasar Modal Penawaran Umum dan Permasalahannya, Citra Aditya Bakti, Bandung, 1995. Pasar Modal, PT. Citra

Aditya Bakti, Bandung, 2000.

Balfas, Hukum Pasar Modal, Tata Nusa, Jakarta, 2006.

Black's Law Dictionary (2019) Insider trading, 11th edition, Thomson Reuters.

David L. Ratner et.al, Securities Regulation: Cases and Materials, Forth editions,
West Publishing Co.St.Paul, Minn, 1991.

Donald C. Langervoort, Insider Trading Regulation, Clark Boardman Co. Ltd, Nashville, Tennessee, 1989.

Edy Santoso, Pengaruh Era Globalisasi Terhadap Hukum Bisnis di Indonesia, Kencana, Jakarta, 2018.

Hulwati, Transaksi saham di Pasar Modal Indonesia, UII, Yogyakarta, 2001.

Jusuf Anwar, Pasar Modal Sebagai Sarana Pembiayaan Dan Investasi, Alumni, Bandung, 2005.

Martalena Maya Malinda, Pengantar Pasar Modal, Edisi Revisi.

Munir Fuady, Pasar Modal Modern: Tinjauan Hukum, PT. Citra Aditya Bakti, Bandung, 1995. , Pengantar Hukum Bisnis, PT.

Citra Aditya Bakti, Bandung, 2002.

Najib A. Gisymar, Insider Trading Dalam Transaksi Efek, PT. Citra Aditya Bakti, Bandung, 1999.

Oslon, et.al, Recent Insider Trading Developments: The search of Clarinfy, 85 Northwestern University Law Review 715, 1991.

Panji Anoraga dan Piji Pakerti, Pengantar Pasar Modal, Rineka Cipta, Jakarta, 2008.

Paulus Situmorang (2011), Pengantar Pasar modal, Mitra Wacana Media, Jakarta.

Prathama Raharja, (1989), Kamus Pasar Uang dan Modal, Lembaga, FE UI. Jakarta.

Roger E. Meiners, et.al, The Legal Environment of Business, Third edition, west Publishing, St. Paul, 1988, hlm. 575, sebagaimana dikutip dalam Najib A. Gisymar, Insider Trading Dalam Transaksi Efek, PT. Citra Aditya Bakti, Bandung, 1999.

Romli Atmasasmita, Pengantar Hukum Kejahatan Bisnis, Cet. Ke-2, Prenada Media, Jakarta, 2003.

Sofyan A. Djalil, Manipulation and Insider Trading, Makalah pada pendidikan dan pelatihan bagi profesional penunjang untuk konsultan hukum pasar modal, angkatan VII LMKA-BPLK, Jakarta, 21 Oktober-8 Nopember 1996. 
Suad Husnan (2005), Dasar-dasar Teori Portofolio dan Analisis Sekuritas, UPP STIM YKPN, Yogyakarta.

Sunariyah (2011), Pengantar Pengetahuan Pasar Modal, UPP STIM YKPN, Yogyakarta.

Steve $\mathrm{H}$, Hanke dan Alan Walters (Ed), tanpa judul buku, ICS Press, San Fransisco, USA, 1991,

Syarir, Tinjauan Pasar Modal, Gramedia Pustaka Utama, Jakarta, 1995.

Tavinayati Yulia Qamariyanti, Hukum Pasar Modal di Indonesia, Sinar Grafika, Jakarta, 2009.

Tjiptono Darmadji dan Hendy M. Fachruddin (2006), Pasar Modal di Indonesia, Salemba Empat, Edisi 3.

\section{Sumber Lain :}

Undang-undang Pasar Modal Republik Indonesia Nomor 8 Tahun 1995.

Bismar Nasution, Keterbukaan Dalam Pasar Modal, Universitas Indonesia, Fakultas Hukum, Program Pascasarjana, 2001.

Djuhaendah Hasan, Hukum Perdata Sebagai Landasan Hukum Bisnis, Program Pascasarjana, UNPAD, Magister Hukum BKU Hukum Bisnis, Jakarta, 2005.

Dosen Pendidikan.Com (2020). Pasar Modal Pengertian, Makalah, Fungsi, Peran dan Produknya.

https://www.dosenpendidikan.co.id/pa sar-modal/

Elvira Taufani, Penegakan Hukum di Pasar Modal, Dalam Tim Penyusun, Sumber Cahaya, Simbur Cahaya No. 27 Tahun X, 2005.

Ferdy Hasiman, Bapepam Minta UU Pasar Modal Segera Diamankan, http://www.inilah.com, diakses pada bulan Desember 2009.

I Nyoman Tjager, Pokok-pokok Materi Undangundang Psar Modal, Buku Seminar Potensi-potensi Kejahatan di Bursa Efek, Senat Mahasiswa Fakultas Hukum UGM, Yogyakarta, 28 September 1996.

M.S. Tumangor, Kajian Hukum Atas Insider Trading di Pasar Modal Suatu Antisipasi Terhadap Pengembangan Ekonomi Indonesia, Dalam Warta Bapepam, Edisi 8 Agustus 2005, Jakarta.
Najib, Tinjauan Umum Terhadap Pasar Modal Indonesia, Makalah diskusi pada mata kuliah hukum perusahaan, Program Magister IImu Hukum UII, 18 Januari 1997.

Samsul Maarif, PTRO, BEI Curigai Philip Securities, http://www.inilah.com, diakses pada bulan Desember 2009.

Pajarrahmatuloh.blogspot.com (2015). Insider Trading (Diskusi Seputar Hukum). https://pajarrahmatuloh.blogspot.com/2015/0 4/insider-trading.html 